\title{
50 VUOTTA TÄYTTÄVÄ SIGNUM ON UUDISTUNUT
}

Luet graafisen suunnittelijan ja kuvataiteilijan Petri Fillsin uudistamaa, tänä vuonna 50 vuotta täyttänyttä Signumia. Lehden visuaalisen ilmeen uudistuksen on mahdollistanut Tiedekustantajain liiton apuraha, joka on rahoitettu Kopioston keräämillä tekijänoikeuskorvauksilla. Viimeksi näin suuri uudistus Signumin ulkoasussa on toteutettu vuonna 2000 .

Seuran historiateos julkaistaan marraskuussa 2018 ja sain kurkata etukäteen sen Signum-osiota. Siinä kolme päätoimittajaa - Martti Blåfield, Tuula Ruhanen ja Päivikki Karhula - muistelee kiinnostavasti ja hauskasti lehden vuosikymmeniä.

STKS alkoi julkaista monistettua tiedotetta vuonna I955. Vuonna 1968 todettiin, että oli aika tehostaa seuran viestintää ja yhdeksi hyväksi kanavaksi päätettiin perustaa lehti, joka julkaisisi artikkeleita. Nimiehdotuksia pyydettiin seuran jäseniltä ja Anna-Maija Kurikan ehdotus Signum valittiin. Aluksi lehdessä oli kahdeksan sivua, se ilmestyi kymmenen kertaa vuodessa ja sen painos oli 350 kappaletta. Vuonna 2018 Signumissa on yleensä 36 sivua, se ilmestyy neljä kertaa vuodessa ja sen painos on 800 kappaletta.

Ensimmäisen päätoimittajan, Martti Blåfieldin, pesti oli paljon laajempi kuin nykyisin: päätoimittaja oli "konekirjoittaja, oikolukija, taittaja, postittaja, ilmoitushankkija, kirjoittaja, seuraavien lehtien suunnittelija, laskuttaja, kirjanpitäjä ym." (Blåfield, Karhula ja Ruhanen 20r8). Lisäksi hän kantoi lehtinippuja postiin. Uhraukset eivät päättyneet siihen: oli vuosi, jolloin päätoimittaja Blåfield kuittasi Signumin kirjapainolaskun perheensä asuntolainalla.

Lisää Signumista ja stкs:n lähes 90-vuotiaasta taipaleesta voit lukea Tuula Ruhasen ja Marja Sarvilinnan toimittamasta historiateoksesta.

Tässä Signumin kaksoisnumerossa on tarjolla konferenssikuulumisia kotimaasta ja ympäri maailmaa, kirjastohanke Eritreassa, pohdintaa työelämäpedagogiikasta sekä Leidenin manifestista.

Ensi vuonna, vuoden 2019 ensimmäisestä Signumista, pääset lukemaan Petri Fillsin kirjoitusta Signumin visuaalisen ilmeen uudistuksen suunnittelusta.

Huomasitko jo, että myös seuran verkkosivut ovat uudistuneet?

\section{Lähde:}

Blåfield, Martti, Karhula, Päivikki ja

Ruhanen Tuula, 2018:

"Signum-lehti - tieteellisten kirjastojen

yhteinen ääni”. Ilmestyy marraskuussa

2018 Tuula Ruhasen ja Marja

Sarvilinnan toimittamassa sTKs:n

historiateoksessa.

Johanna Labikainen 